\title{
Habitat Selection by Large Mammals in South Luangwa National Park, Zambia
}

\author{
Harry Chabwela ${ }^{1}$, Chansa Chomba ${ }^{2 *}$, Gilson Kaweche ${ }^{3}$, Ackme Mwenya ${ }^{3}$ \\ ${ }^{1}$ Department of Biological Sciences, University of Zambia, Lusaka, Zambia \\ ${ }^{2}$ School of Agriculture and Natural Resources, Disaster Management Training Centre, Kabwe, Zambia \\ ${ }^{3}$ Department of National Parks and Wildlife Service, Chilanga, Zambia \\ Email: *chansachomba@rocketmail.com,ritachansa@yahoo.com,cchomba@mu.ac.zm
}

How to cite this paper: Chabwela, $\mathrm{H}$., Chomba, C., Kaweche, G. and Mwenya, A. (2017) Habitat Selection by Large Mammals in South Luangwa National Park, Zambia. Open Journal of Ecology, 7, 179-192. https://doi.org/10.4236/oje.2017.73013

Received: January 9, 2017

Accepted: March 12, 2017

Published: March 15, 2017

Copyright (c) 2017 by authors and Scientific Research Publishing Inc. This work is licensed under the Creative Commons Attribution International License (CC BY 4.0).

http://creativecommons.org/licenses/by/4.0/

\section{(c) (i) Open Access}

\begin{abstract}
An assessment to determine habitat selection by large mammals was carried out in South Luangwa National Park, eastern Zambia. We divided Habitat types into five groups based on physiognomic classification as: savannah woodland, back swamp, Combretum thicket, Mopane woodland, and TerminaliaErythrophleum. Road count method was used to sight animals across the four identified habitat types. Results showed that puku, impala, elephant, and zebra were highly selective of habitat types. Puku occurred mainly in back swamp habitat $(86.6 \%)$ followed by water buck (75.0\%), elephant (72.3\%) and zebra (65.7\%). Impala were more abundant in Terminalia-Erythrophleum woodland (69.50\%) while buffalo was mainly sighted in Mopane-woodland (45.07\%). Other species were more cosmopolitan. It was suggested that foraging behaviour, season and security with respect to predation were the factors singularly or collectively that influenced the observed pattern of habitat selection by large mammals.
\end{abstract}

\section{Keywords}

Assessment, Foraging, Road Count, Occurrence, Physiognomic Classification

\section{Introduction}

A suitable habitat is an important environmental factor affecting the distribution and abundance of wild animals. Choice of a proper habitat determines whether an animal population will survive and grow or not. It is one of the most basic behaviourally mediated processes in an animal's life and critical for a species long-term survival because it guarantees access to food, water, and cover which are the most important welfare factors [1]. Although studies on habitat selection are still limited in Zambia, contributions elsewhere [2] provide a good argument 
on its significance in the management of wild animals and protected areas in general. In particular, wildlife managers tend to agree that growing human population, increasing food demand, human settlements and habitat disturbances resulting from anthropogenic developments and resource exploitation are major factors in habitat destruction and declining animal populations [3]. A clear understanding of animal habitat-relationship is therefore, essential for effective protected area management. Since South Luangwa National Park is considered to be among the most critical areas to wildlife conservation in the country due to its high diversity and abundance of species, it was inevitable to carry out this study in order to improve research and monitoring of the wildlife habitat. The main objectives of the study were to: 1) determine species distribution, abundance and habitat selection, 2) identify habitats that were most significant for selected large mammals in the area, and 3) explain the relationship between large mammals and their habitats and further bring this information to planners and managers to stimulate debate in habitat and wildlife conservation.

\section{Methods and Materials}

\subsection{Study Area Description}

\subsubsection{Location}

The study was conducted in South Luangwa National Park (SLNP) which is located between $30.50^{\circ} \mathrm{E}-32.50^{\circ} \mathrm{E}$ and $12.15^{\circ} \mathrm{S}-14.00^{\circ} \mathrm{S}$ in the North-East of Zambia within the Luangwa Valley (Figure 1). The National Park is approximately 9050 $\mathrm{km}^{2}$ in extent and lies mainly between Muchinga escarpment in the west and the Luangwa River in the east except for the Nsefu area and the Luamfwa area in the southern end where both sides of the Luangwa River are inside the National

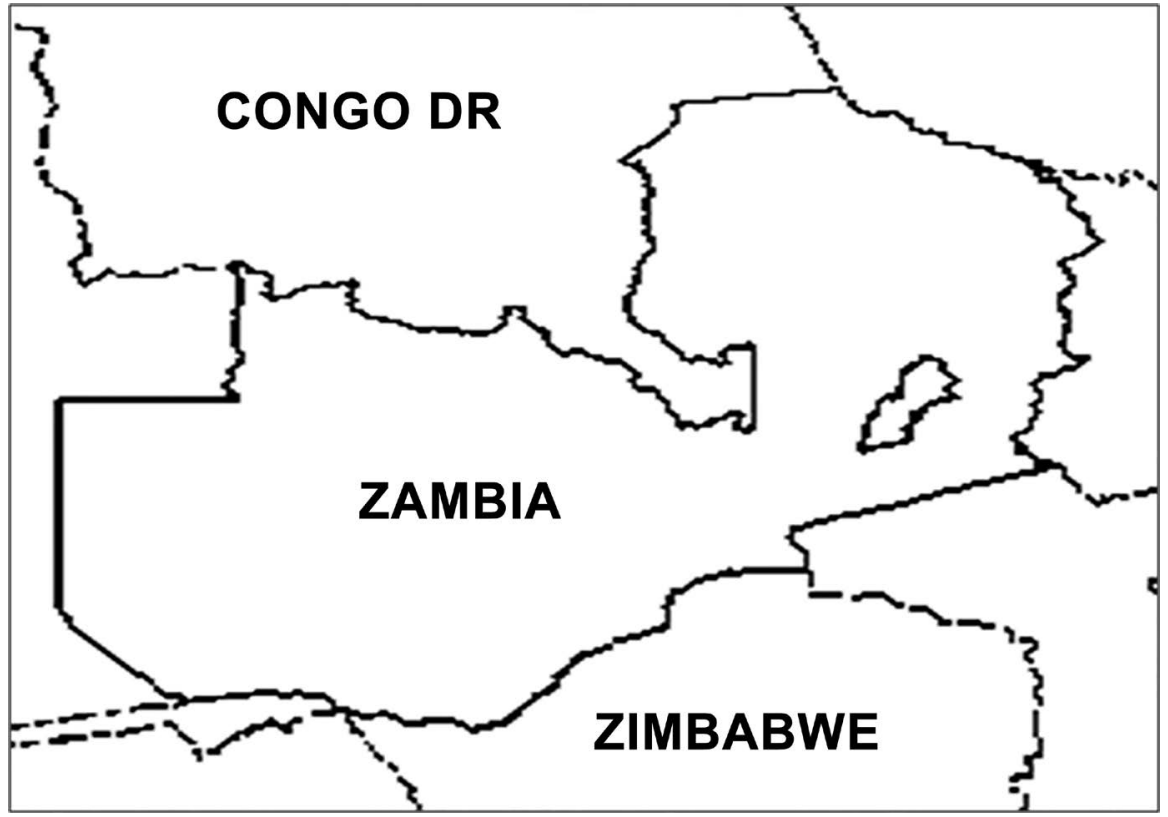

Figure 1. Location of study area and physical features, South Luangwa National Park, Zambia. [Modified after Chomba et al. 2014]. 
Park. The general elevation ranges from $580 \mathrm{~m}$ above sea level at the river bed to $760 \mathrm{~m}$ above sea level at the foot of the escarpment. The exact location of the study site was in the Mfuwe area along the Musilashi and Katete streams including the Mbangula and Mfuwe lagoons and areas near Chichele hot spring (Figure 2).

\subsubsection{Climate}

The climate of the area is characterized by three distinct seasons; hot, wet and dry seasons from November to April; cool dry season from May to August and hot dry season from September to early November [4]. The mean annual rainfall is $800 \mathrm{~mm}$ while the mean temperature range is from $32^{\circ} \mathrm{C}$ to $36^{\circ} \mathrm{C}$ in the hot season. The minimum temperature in the cold season is $15^{\circ} \mathrm{C}$ [1].

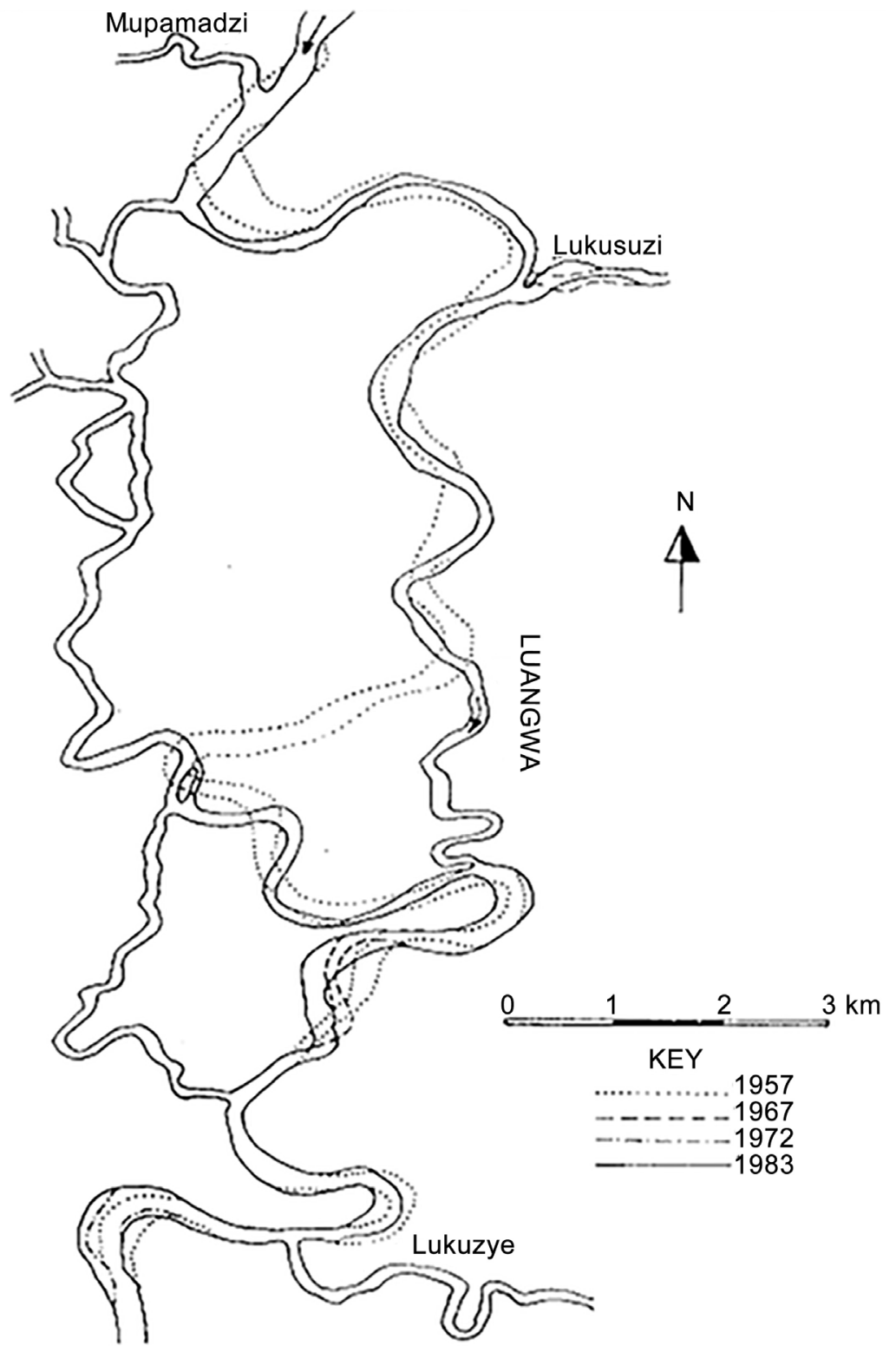

Figure 2. Study site details and meandering of the Luangwa River, South Luangwa National Park, Zambia. [Modified after Chomba et al. 2014]. 


\subsubsection{Soils}

Soils of the South Luangwa National Park have been described in detail by several authors as being varied and are a result of valley formations characterized by the colluvial soil type on the Muchinga escarpment while the reddish-brown terscillitic soil predominates the dissected hilly area [1]. The recent alluvial soils are known to be characterized by a mixture of deep, sandy and swampy soils along the flood plain.

The general vegetation of the National Park has been well described [1]. It is generally characterized by the flood plain woodland which is maintained by the meandering Luangwa River's channel's (Figure 3) and seasonal flooding [2].

\subsubsection{Vegetation}

The common plant species on the valley floor include; Diospyros mespiliformis Hochst, Trichilia emetica Vahl, Salix suberrata Wild, Faidherbia (Acacia) albida Delile, Oncoba spinosa Forsk, Kigelia africana (Lam) Benth, Combretum im-
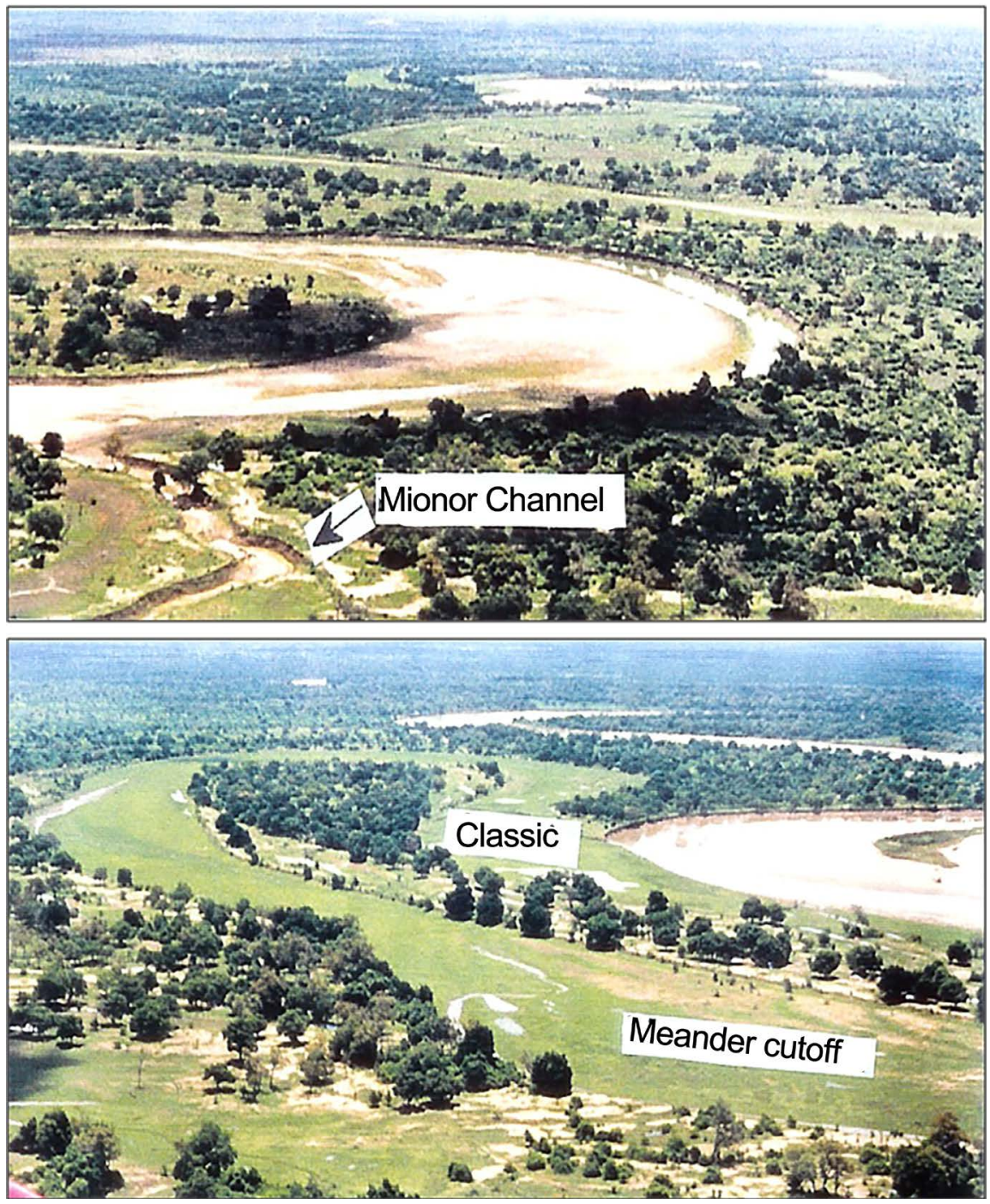

Figure 3. Luangwa river occasional meandering causes flooding which promotes depositions that enhance fertility of alluvial soils. [Modified after Chomba et al. 2014]. 
berbe Wawra and Xeroderrisstuhlmanni Taub. The three species Colophosphermum mopane Kirk ex Benth is dominant in the dry shallow sandy and clay soils. Grass species include Echinochloa colona (Linn) Link, Setaria sphacelata (Schumach.) Stapf and Hubbard, Brachiaria brizantha Stapht and Digitaria sp. The vegetation on the escarpment and the hills is dominated by Miombo (Genera; Brachystegia, Julbernardia and Isoberlinia) woodland with common species being Brachystegiaallenii Burtt Davy and Hutch, B. spiciformis Benth, Burkea africana Hook, Julbernardia globiflora (Benth) Troupin [5]-[10].

\subsubsection{Habitat Classification}

Habitats were classified according to vegetation physiognomic characteristics as earlier described [1]. Five habitat types were classified as follows:

1) Savannah woodland-this habitat occurred on the soils ranging from deep alluvial soils to shallow red soils and the predominat plant species included Faidherbia (Acacia) albida, Kigelia pinnata, Trichilia emetica, Combretum ghasalense, Securinega virosa, Xeroderris stuhlmannii and Diospyros mespiliformis. Grass species were mostly Hyparrhenia rufa (Nees) Stapf, Andropogon sp. Linn. and Cymbopogon excavates (Hochst) Stapt.

2) Back swamp-this habitat type is subjected to seasonal flooding during high flood peaks and is mainly associated with lagoons, swales and levees of the main river channel. Soils are deep alluvial types which support plant species characterized by Echnochloa colona, E. Pyramidalis (Lam), Setaria sphacelata, Phragmites mauritianus Kunth., and the main tree species include Combretumimberbe, Faidherbia (Acacia) albida, Onchoba spinosa, Salix subserrata, and phyllanthus reticulates Poir).

3) Combretum thicket-this habitat occurs on dry red soils, and comprises plant species such as Combretum obovatum F. Hoffin, C. elaeagnoides Klotzsch, Dichrostachys africana Brenaand Brummit, D, cinerea L) WeighandArn, Diospyros senensis Klotzsch, Markhamia sp. Seem.exBaillon, Schrebera tricholada Wehv, Cassia abbreviata Oliverand Capparis tomentosa La, which is mainly associated with termite mounds.

4) Mopane woodland this is the major habitat type on the river valley floor, supported by valley sandy soils on high ground and by clay soils in lower areas. The main plant species are Colophospermum mopane, Ximenia, americana L., Combretum obovatum, Euphorbia sp., Balanites aegytiaca, Commiphora sp., and Capparis tomentosa.

5) Terminalia Erythrophleum this habitat is limited in occurrence and is mainly confined to sandy soils. Characteristic plant species include Terminalia sericea, Erythrophleum africanum Markhamia occuminata, Cassia abbreviata, and common grasses are, Andropogon sp., and Hyparrehenia sp.

\subsection{Animal Counts}

We estimated the distribution of large mammal species by using the Road Strip Census Method earlier described [4] [5] [6] [7] [8]. Transects were established 
along an accessible road through five habitat types. The census was done by two observers while driving along the road at a speed between $15-20 \mathrm{~km}$ per hour, and counted and recorded all animals seen within a strip of approximately $50 \mathrm{~m}$ on either side. Observations were carried out twice a day for 15 days between 07:00 hours and 09:00 hours and between 16:00 hours and 18:00 hours, because this is the time when temperatures are relatively low and animals are active. Observations focused on six commonly occurring species [9]. These were; impala (Aepyceros melampus, Lichtenstein 1812), puku (Kobus vardoni, Evxleben, 1777), zebra (Equus bohemii (burchelli)) Gmelin 1788), water buck (Kobus ellipsiprymnus, Orgiby 1833) Buffalo (Syncerus caffer), Sparrman and the African elephant (Loxodonta africana Blumenbach).

Habitat selection was evaluated based on the following; 1) habitat preference which was defined as density of a species in habitat by total density of species [8] and 2) Affinity index which was calculated as percent total counts of the species in habitat $x$ divided by percent availability of habitat $x$ [11]-[20]. This was intended to eliminate bias from differential habitat availability. The Chi Square Test [21] was used to determine whether or not distribution of a species was random as against the alternative that it was attributed to habitat preference.

\section{Results}

\subsection{Animal Distribution}

Results showed that puku had very high presence in back swamp habitat (86.6\%) followed by water buck (75.0\%), elephant (72.3\%) and zebra $(65.7 \%)$ on the same habitat (Figure 4, Table 1). Impala however, were more common in Terminalia-Erythrophleum (69.50\%) and less in Combretum thicket (12.10\%) and

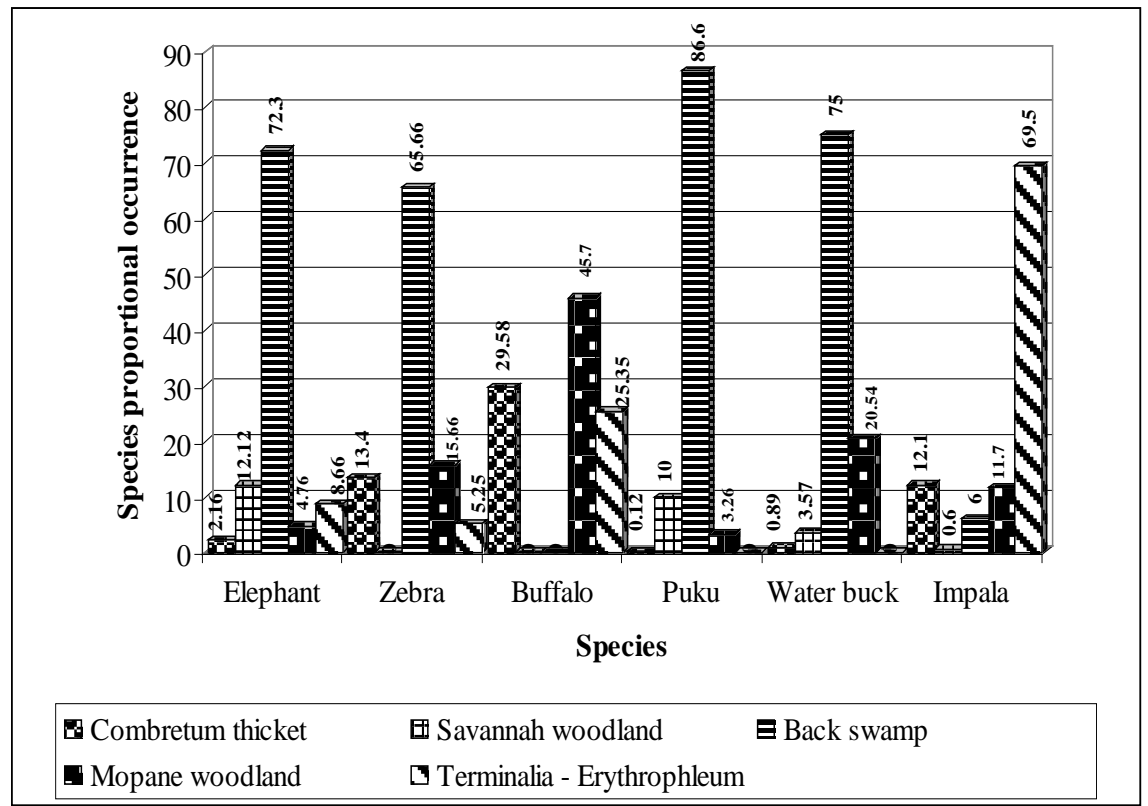

Figure 4. Species distribution in five habitat types based on proportions of occurrence in each habitat type. 
Mopane woodlands (11.70\%), while buffalo were mostly encountered in Mopanewoodland (45.07\%) (Table 1), and less common in Combretum thicket (29.58\%) and Terminalia-Erythrophleum (25.35\%). Zebra were observed in Combretum thicket (29.58\%) and Terminalia-Erythrophleum (25.35\%). Elephant was recorded also in woodland savanna (12.12\%) (Table 1, Figure 4).

\subsection{Animal Density}

Densities of species in each of the habitats are given in Table 2. Impala had high density in Terminalia-Erythrophleum $315.1 / \mathrm{km}^{2}$ and in Combretum thicket habitat $54.8 / 1 \mathrm{~km}^{2}$. In back swamp habitat puku had $276.1 / \mathrm{m}^{2}$, elephant $64.5 / \mathrm{km}^{2}$, zebra $43.6 / \mathrm{km}^{2}$ and water buck $32.4 / \mathrm{km}^{2}$ (Table 2). Buffalo, water buck and zebra recorded relatively low densities in nearly all the habitats studied (Table 2).

\subsection{Habitat Preference and Habitat Affinity}

The most preferred habitat type was the back-swamp with puku recording the highest $(76.33 \%)$, followed by water buck $75.02 \%$, elephant $72.15 \%$ and zebra $65.66 \%$ (Table 3, Figure 5). Impala was to some extent cosmopolitan showing presence in all habitats, but higher in Terminalia-Erythrophleum $69.50 \%$ followed by Combretum-thicket habitat $12.1 \%$ and Mopane-woodland habitat $11.70 \%$. Back-swamp and woodland-savannah were least preferred by impala

Table 1. Large mammal species densities per square kilometer in each of the five habitat types.

\begin{tabular}{cccccc}
\hline Species & $\begin{array}{c}\text { Combretum } \\
\text { thicket }\end{array}$ & $\begin{array}{c}\text { Woodland } \\
\text { savanna }\end{array}$ & $\begin{array}{c}\text { Back } \\
\text { swamp }\end{array}$ & $\begin{array}{c}\text { Mopane } \\
\text { Woodland }\end{array}$ & Terminalia-Erythrophleum \\
\hline Buffalo & 8.90 & 0.00 & 0.00 & 12.40 & 6.90 \\
Elephant & 1.90 & 10.80 & 64.50 & 4.50 & 7.70 \\
Impala & 54.8 & 2.70 & 27.40 & 0.90 & 315.10 \\
Puku & 0.39 & 32.00 & 276.40 & 53.30 & 0.00 \\
Water & 0.39 & 1.50 & 32.40 & 8.90 & 0.00 \\
buck & 8.90 & 0.00 & 43.60 & 10.40 & 3.50 \\
Zebra & & &
\end{tabular}

Table 2. Species distribution in each of the five habitat types based on proportion of occurrence.

\begin{tabular}{cccccc}
\hline \multirow{2}{*}{ Species } & \multicolumn{5}{c}{ Habitat type } \\
\cline { 2 - 5 } & $\begin{array}{c}\text { Combretum } \\
\text { thicket }\end{array}$ & $\begin{array}{c}\text { Woodland } \\
\text { savanna }\end{array}$ & $\begin{array}{c}\text { Back } \\
\text { swamp }\end{array}$ & $\begin{array}{c}\text { Mopane } \\
\text { Woodland }\end{array}$ & Terminalia-Erythrophleum \\
\hline Buffalo & 29.58 & 00.00 & 00.00 & 45.07 & 25.35 \\
Elephant & 02.16 & 12.12 & 72.30 & 04.76 & 08.66 \\
Impala & 12.10 & 00.60 & 06.00 & 11.70 & 69.50 \\
Puku & 00.12 & 10.00 & 86.60 & 03.26 & 00.00 \\
Water & 00.89 & 03.57 & 75.00 & 20.54 & 00.00 \\
buck & 13.40 & 00.00 & 65.70 & 15.70 & 05.23 \\
Zebra & & & &
\end{tabular}


Table 3. Species habitat preference in each of the five habitat types, South Luangwa National Park, Zambia.

\begin{tabular}{cccccc}
\hline Species & $\begin{array}{c}\text { Combretum } \\
\text { Thicket }\end{array}$ & $\begin{array}{c}\text { Woodland } \\
\text { Savanna }\end{array}$ & $\begin{array}{c}\text { Back } \\
\text { Swamp }\end{array}$ & $\begin{array}{c}\text { Mopane } \\
\text { Woodland }\end{array}$ & Terminalia-Erythrophleum \\
\hline Buffalo & 31.56 & 00.00 & 00.00 & 43.42 & 24.47 \\
Elephant & 02.12 & 12.08 & 72.15 & 05.03 & 08.61 \\
Impala & 13.67 & 00.67 & 06.83 & 00.22 & 78.60 \\
Puku & 00.11 & 08.84 & 76.33 & 14.72 & 00.00 \\
Water & 00.90 & 03.47 & 75.02 & 20.60 & 00.00 \\
buck & 13.40 & 00.00 & 65.66 & 15.66 & 05.25 \\
Zebra & & & & & \\
\hline
\end{tabular}

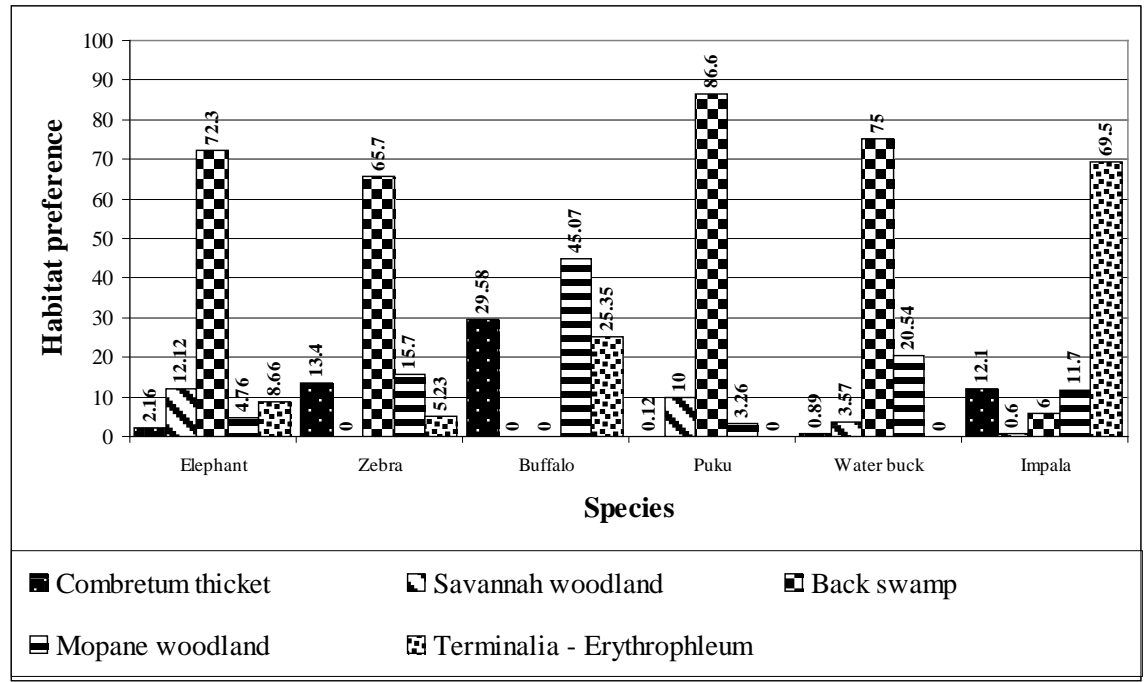

Figure 5. Species habitat preference in each habitat type, South Luangwa National Park, Zambia.

with $6.0 \%$ and $0.6 \%$ respectively. Buffalo did not show preference for woodlandsavanna and back-swamp habitats, but Mopane-woodland $45.07 \%$ followed by Combretum-thicket 29.58\% and Terminalia-Erythrophleum 25.35\% (Table 3). Elephant showed preference for back-swamp $72.3 \%$ followed by woodland-savanna habitat $12.12 \%$. There were only two species that showed affinity for all the habitats studied (Table 4, Figure 6). Elephant showed high affinity values for back-swamp habitat 16.6 and impala had high affinity for Terminalia-Erythrophleum habitat 5.33 (Table 4). Although high values of Affinity Index were expressed in back swamp habitat as given by puku 18.22, elephant 16.6, zebra 4.56 and water buck 14.12, only Mopane-woodlands and Combretum-thicket habitats had recorded Affinity Index values by all species.

Species distributions, habitat preference and affinity for each habitat were tested using Chi-Square $\left(\chi^{2}\right)[12]$ and the values are given in Table 5. Habitat selection by the six species studied rejected the null hypothesis as our data supported the view that a significant difference existed between the expected and the actual values when we tested using proportions and at critical values of habitat 
preference values $\alpha=0.05$ and $\chi^{2}=0.01$ (Table 5). These values indicated that the distribution and habitat preference were not random and free. Nevertheless, when Affinity Index (AI) was tested, only the elephant and puku showed significant difference while impala, zebra and water buck indicated no difference in the selection of habitats studied.

Table 4. Species habitat selection as given by Affinity Index of each habitat type.

\begin{tabular}{|c|c|c|c|c|c|}
\hline Species & $\begin{array}{c}\text { Combretum } \\
\text { thicket }\end{array}$ & $\begin{array}{l}\text { Woodland } \\
\text { savanna }\end{array}$ & $\begin{array}{c}\text { Back } \\
\text { swamp }\end{array}$ & $\begin{array}{c}\text { Mopane } \\
\text { Woodland }\end{array}$ & Terminalia-Erythrophleum \\
\hline Buffalo & 0.86 & 0.00 & 00.00 & 1.26 & 0.72 \\
\hline Elephant & 0.52 & 2.90 & 16.60 & 1.14 & 2.08 \\
\hline Impala & 0.92 & 0.05 & 00.46 & 0.90 & 5.33 \\
\hline Puku & 0.03 & 2.17 & 18.22 & 0.70 & 0.00 \\
\hline $\begin{array}{l}\text { Water } \\
\text { buck }\end{array}$ & 1.00 & 0.19 & 04.12 & 1.10 & 0.00 \\
\hline Zebra & 0.93 & 0.00 & 04.56 & 1.07 & 0.35 \\
\hline
\end{tabular}

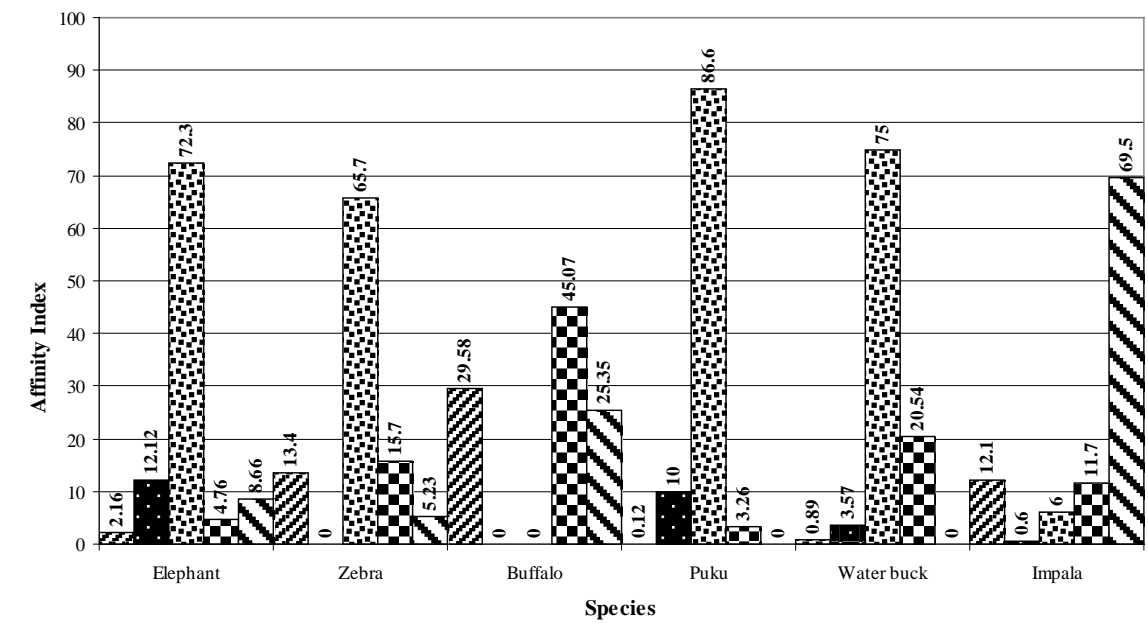

G. Combretum thicket

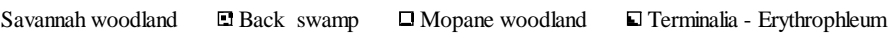

Figure 6. Habitat selection by six wildlife species as given by Affinity Index in five habitat types, South Luangwa National Park, Zambia.

Table 5. Chi Square values based on proportions, habitat preference and Affinity Index of each habitat type.

\begin{tabular}{cccc}
\hline Species & $\begin{array}{c}\chi^{2} \text { values based on } \\
\text { proportions }\end{array}$ & $\begin{array}{c}\chi^{2} \text { values based on } \\
\text { habitat preference }\end{array}$ & $\begin{array}{c}\chi^{2} \text { values based } \\
\text { on Affinity Index }\end{array}$ \\
Buffalo & 37.44 & 74.03 & 1.03 \\
Elephant & 173.81 & 172.79 & $39.10^{*}$ \\
Impala & 35.13 & 220.82 & 12.11 \\
Puku & 240.86 & 206.04 & $54.54^{*}$ \\
Water buck & 183.01 & 203.28 & 7.31 \\
Zebra & 118.42 & 138.51 & 8.33 \\
\hline
\end{tabular}

Significant at $\alpha=0.05$ with $\mathrm{df}=4$ Significant at $\alpha=0.01$ with $\mathrm{df}=4 \chi^{2} 0.05,4=9.4877 \chi^{2} 0.01=13.086$. 


\section{Discussion}

Habitat selection is viewed as a hierarchical process involving innate and learned behaviourin which an individual decides what habitat it prefers [20]. Equally, results in habitat selection tend to attract varied interpretations because of the type of methodologies and data analyses applied. The argument in this study however, centred on the premise that the occurrence of an individual in a given habitat at the time of census was a result of habitat selection of the available habitats as opposed to whether or not the presence of an individual in a habitat was free and random. Although our results showed that buffalo, impala, waterbuck and zebra had shown habitat selection of the habitats available, it does not necessarily imply that such selection was, for the most part, obligatory or that the species were restricted to the habitats they had selected. We confirmed this when we used Affinity Index values to determine species affinity for the habitat they had selected which showed that the affinity was not significant, meaning that these species had a wide range of habitats from which they could choose.

Previous studies have shown that waterbuck generally a riparian species usually occurs in woodland along streams, rivers or dambos [14] [15] [16]. The species is predominantly a grazer, and exhibits great dependence on water. Although water and grazing have a great effect on the distribution of the species as given in our results, other studies [17] have shown that the species' selection of a habitat is also influenced by territorial behaviour.

Similarly, reasons are not clear for the lack of selection of woodland-savanna habitat by zebra as the species occurs in plains and dambos and in light woodland or mixed savanna [14] [18] [19]. Zebra is largely a bulk grazer and the high preference for back-swamp habitat cannot be explained, because its distribution was expected to extend to a wide range of habitats where grazing material existed.

Impala is largely a browser and an occasional grazer, therefore, it would be expected to have high selection for wooded vegetation where there was adequate browsing material. As Tables 1-3 show, suitable habitats for the species were mainly Terminalia-Erythrophleum, Combretum-thicket and Mopane woodland during the wet season as given in the percent habitat preference and Affinity Index values. The lack of selection for woodland savanna and back swamp suggests that this would be due to the species' browsing habits and a possible indication of poor vegetation structure of the two habitats to provide a suitable and within reach browse for the species. Recent studies on distribution and habitat selection of the species [17] appeared to be influenced by food quality, and this study showed that impala were mostly distributed in grass lands and less frequent in shrub habitat throughout the year. This tends to support our findings which also showed impala sharing less preference for Combretum-thicket as compared to high values in Terminalia-Erythrophleum.

Although there was no significant statistical difference when the Affinity Index values were used in the manner in which buffalo selected its habitats, the 
species' presence in Mopane woodlands, Combretum-thicket and TerminaliaErythrophleum was indicative of the relative preference for these habitats. As for, buffalo it is known that they are generally gregarious and show very active day movements covering wide distances [21]. This explains the lack of distinct pattern in species habitat preference recorded in this study. Since buffalo is predominantly a grazer, one would have expected them to give high preference values for back-swamp and woodland-savanna. But as the results show, this was not the case; the choice for woody vegetation could be speculated as being attributed to predation avoidance [14] [20]. Other factors which affect buffalo distribution patterns have been discussed elsewhere [20] [21] [22] and their findings revealed that buffalo distribution was influenced by water and nutrient contents in food plants.

Both elephant and puku were the only species that showed a statistical significance when affinity values were tested using Chi Square Test for their affinity for the back-swamp habitat. Our views on this matter might be conjectural but probable. Puku is generally described as a wetland species usually inhabiting dambos, marshy areas and flood plains [14] [23]-[29], but the habitat includes marginal woody areas. Puku is a specialized species and cannot switch diet like other species. Thus the high values of their presence and the high affinity for the back-swamp habitat were expected as the species is predominantly a grazer. However, although behavioural aspects of the species were not considered in this study, the distribution of the species is equally affected by its territorial behaviour [30] [31], and their also studies revealed that puku exhibited lekking behaviour in males as earlier described [32] [33] in studies on the congeneric species. Therefore, we can certainly suggest that it is highly probable that the distribution of the species may have been affected by territorial behaviour.

Elephants are bulky feeders and results show that they occurred in every habitat. However, the high values for habitat preference for back-swamp and woodland-savanna and equally high values of Affinity Index for the same habitats would signify the predominance of grazing habits by the species during this time of the year. Earlier investigations [34] on elephant feeding behaviour explain this relationship as they revealed very high proportions of grass intake during the wet season as contrasted with the browse values. Further observations [34] showed that wherever the species was sighted, the feeding pattern showed high preference for grass in the wet periods, and that the animal would turn to browse only in the dry season, after grass had withered. Similarly, [34] the distribution and space use patterns within individual home ranges of elephants coincided with seasonal climatic changes and the corresponding change in food and water availability. Other observations [35] showed that the movements of elephants in Luangwa valley were restricted to the river bed strip during the wet season and reciprocal dispersal across the valley during the dry period. This phenomenon perhaps may explain the high concentration of elephants in our study area during this period. 


\section{Conclusion}

Studies on habitat selection tend to point on several aspects that might require serious consideration in wildlife and protected area conservation. Critics have maintained that while there are variations and limitations in research methologies in data collection and data analysis involving habitat selection, studies have tended to oversimplify the habitat selection theory. This concern has been raised in some discussions [36] [37] and we strongly suggest that in habitat classification studies such as those involving species choice for areas for their survival, a multivariate analysis approach would be appropriate to allow for interacting variables of habitat structure and behaviour of animals as these are affected simultaneously by many biotic and abiotic factors [38]. Advances in this field of ecological research have given satisfactory results [39] [40] and is worth pursuing in future studies in the Luangwa Valley and elsewhere.

\section{References}

[1] Sichingabula, H. (1998) Hydrology, Character of Channel Changes on Luangwa River, Their Impacts and Implications on Tourism, South Luangwa National Park and Adjacent Game Management Areas. Report Prepared for EDF/NPWS towards the Development of a General Management Plan for South Luangwa National Park and Adjacent Game Management Areas, Chilanga.

[2] Lamphrey, H.F. (1963) Ecological Separation of the Large Mammal Species in the Tarangire Game Reserve, Tanganyika. East African Wildlife Journal, 1, 63-92. https://doi.org/10.1111/j.1365-2028.1963.tb00179.x

[3] Chomba, C., Nyirenda, V. and Silengo, M. (2013) Selective Pattern of Woody Plant Speciesutilization by Local Communities in Mumbwa Game Management area: A Management Prerequisite for Effective Management of Woodland Resources and Benefit Sharing. Open Journal of Ecology, 3, 532-550. https://doi.org/10.4236/oje.2013.38062

[4] Ansell, W.F.H. (1965) Hippo Census on the Luangwa River. Puku, 3, 15-27.

[5] Garstang, M., Davis, R.E., Legget, K., Frauenfeld, O.W. and Greco, S. (2014) Response of Africa Elephants (Loxodonta africana) to Seasonal Changes in Rainfall. PLoS ONE, 9, e108736. https://doi.org/10.1371/journal.pone.0108736

[6] Storrs, A.E.G. (1995) Know Your Trees: Some of the Common Trees Found in Zambia. Regional Soil Conservation Unit.

[7] Sinclair, A.R.E. and Grimsdell, J.J.R. (1982) Population Dynamics of Large Mammals. African Wildlife Foundation, Nairobi.

[8] Chomba, C. (2012) Factors Regulating the Luangwa (Zambia) Hippopotamus Population within Carrying Capacity Band. International Journal of Biodiversity and Conservation, 5, 109-121.

[9] Chomba, C., Simpamba, T., Kampamba, G. and Nyirenda, V. (2013) Does the Luangwa Hippo Population Size and Density Distribution Vary between Upper and Lower Study Blocks? What Are the Management Implications? Open Journal of Ecology, 4, 262-280. http://www.scirp.org/journal/OJE/ https://doi.org/10.4236/oje.2014.45025

[10] Storrs, A.E.G. (1995) Know Your Trees: Some of the Common Trees Found in Zambia. Regional Soil Conservation Unit, Nairobi.

[11] Jachmann, H. (2001) Estimating Abundance of African Wildlife: An Aid to Adap- 
tive Management. Journal of Wildlife Management, 1391, 40-47. https://doi.org/10.1007/978-1-4615-1381-0

[12] Dasmann, R.F. and Mossman, A.S. (1980) Road Strip Counts for Estimating Numbers of African Ungulates. Journal of Wildlife Management, 26, 101-104. https://doi.org/10.2307/3798176

[13] Davis, D.E. (1982) Hand Book of Census Methods for Terrestrial Vertebrates. CRC Press, Boca Raton.

[14] Conner, R.N. and Dickson, J.G. (1980) Strip Transect Sampling and Analysis for Avian Habitat Studies. Wildlife Society Bulletin, 8, 4-10.

[15] Bohrerl, G.S., Pieter, A.B., Ngene, S.M., Skidmore, A.K. and Douglas-Hamilton, I. (2014) Elephants Movement Closely Tracks Precipitation Driven Vegetation Dynamics in a Kenyan Forest-Savanna Landscape. Movement Ecology, 2, 2. https://doi.org/10.1186/2051-3933-2-2

[16] Aryal, A.D., Raubenheimer, S. and Subedi, B. (2010) Spatial Habitat Overlap and Habitat Preference of Himalayan Musk Deer (Moschus chrysogaster) in Sagarmatha (Mt. Everest) National Park, Nepal. Journal of Biological Sciences, 2, 217-225.

[17] Basile, M., Van Mooter, B., Herfindal, I., Martin, J., Lineell, J.D.C. and Odden, J. (2013) Selecting Habitat to Survive: The Impact of Road Density on Survival in a Large Carnivore. PLOS ONE, 8, e65493. https://doi.org/10.1371/journal.pone.0065493

[18] Fowler, J., Cohen, L. and Jarvis, P. (1998) Practical Statistics for Field Biology. John Wiley and Sons, New York.

[19] Morris, D.W. (1989) Density-Dependent Habitat Selection: Testing the Theory with Fitness Data. Evolutionary Ecology, 3, 80-94. https://doi.org/10.1007/BF02147934

[20] Battin, J. and Lawler, J.J. (2006) Cross-Scale Corrections and the Design and Analysis of Avian Habitat Selection Studies.

[21] Halsdorf, S. (2011) Patterns of Resource Use by Grazers in Humid Coastal Savannah in Tanzania.

[22] Gutbrodt, B. (2006) Diet Composition of Wildebeest, Waterbuck and Reedbuck in Relation to Food Quality in a Moist Savanna of Tanzania. Diploma Thesis, Eldge nossiche Techniche Hochschule, Zurich Swiss Fedral Institute of Technology, Zurich.

[23] Spinage, C.A. (1982) A Territorial Antelope: The Uganda Waterbuck. Academic Press, New York, $334 \mathrm{p}$.

[24] Fischhoffa, I.R., Sundaresana, R, Cordingleya, J. and Rubensteina, D.I. (2007) Habitatuse and Movements of Plains Zebra (Equus burchelli) in Response to Prediction Danger from Lions. Behavioral Ecology, 18, 725-729. https://doi.org/10.1093/beheco/arm036

[25] Thaker, M., Vank, A.T., Owen, C.R., Ogden, M.B. and Slotow, R. (2010) Group Dynamics of Zebra and Wildebeest in Woodland Savannah: Effects of Predation Risk and Habitat Density. PLoS ONE, 5, e12758. https://doi.org/10.1371/journal.pone.0012758

[26] Augustine, D.J. (2004) Influence of Cattle Management on Habitat Selection by Impala on Central Kenyan Rangeland.

[27] Treydte, A.C., Baumgartner, S., Heitkönig, I.M.A., Grant, C.C. and Getz, W.M. (2013) Herbaceous Forage and Selection Patterns by Ungulates across Varying Herbivore Assemblages in a South African Savanna. PLOS ONE, 8, e82831. https://doi.org/10.1371/journal.pone.0082831

[28] Bennit, E., Bonyongo, M.C. and Harris, S. (2014) Habitat Selection by African Buf- 
falo (Syncerus caffer) in Response to Landscape Level Fluctuation in Water Availability on Twotemporal Scales. PLOS ONE, 9, e101346.

https://doi.org/10.1371/journal.pone.0101346

[29] Tomlinson, D.N.S. (1981) Effects of the Social Organization of Water Buck (Kobusellipsiprymnus (Ogilby, 1933) on Forage Habitat Utilization in a Rhodesian Game Park. African Journal of Ecology, 19, 327-339. https://doi.org/10.1111/j.1365-2028.1981.tb01070.x

[30] Mitchell, B.L. and Ansell, W.F.H. (1978) Monterey Printing and Packaging Limited. Lusaka. Wildlife of Kafue and Luangwa: A Tourist Field Guide.

[31] Shanghnessy, R.O., Chain, J.W. and Smith, N.O. (2014) Comparative Diet and Habitat Selection of Puku and Lechwe in Northern Botswana. Journal of Mammalogy, 95, 933-942. https://doi.org/10.1644/13-MAMM-A-301

[32] Kingdon, J. (2008) The Kingdon Field Guide to African Mammals. A and C Black, London.

[33] De Vos, A. (1985) Territorial Behaviour among Puku in Zambia. Sciences, 148, 1752-1753. https://doi.org/10.1126/science.148.3678.1752

[34] Barnes, R.F.W. (1982) Elephant Feeding Behaviour in Ruaha National Park, Tanzania. African Journal of Ecology, 20, 123-136. https://doi.org/10.1111/j.1365-2028.1982.tb00282.x

[35] Viljeon, P.J. (1989) Spatial Distribution and Movements of Elephants (Loxodontaafricana) in Northern Namib Desert region of the Kaokoveld, South West

[36] Jones, J. (2001) Habitat Selection in Avian Ecology: A Critical Review. The Auk, 118, 556-562. https://doi.org/10.1642/0004-8038(2001)118[0557:HSSIAE]2.0.CO;2

[37] Morris, W.D. (2003) Towards an Ecological Synthesis: A Case for Habitat Selection. Oecologia, 136, 1-13. https://doi.org/10.1007/s00442-003-1241-4

[38] Aarts, G.M., MacKenzie, B., McConnell, M. and Fedak, J. (2007) Estimating Space-Use and Habitat Preference from Wildlife Telemetry Data. Ecography, 31, 140-160. https://doi.org/10.1111/j.2007.0906-7590.05236.x

[39] Basillea, M.C., Calengea, E., Marboutinc, R. and Andersend, J. (2008) Assessing Habitat Selection Using Multivariate Statistics: Some Refinements of the Ecological-Niche Factor Analysis. Ecological Modeling, 21, 233-240. https://doi.org/10.1016/j.ecolmodel.2007.09.006

[40] Kneib, T., Knauer, F. and Küchenhoff, H. (2007) A General Approach for the Analysis of Habitat Selection. Technical Report Number 001, 2007 Department of Statistics University of Munich, Munich. 
Submit or recommend next manuscript to SCIRP and we will provide best service for you:

Accepting pre-submission inquiries through Email, Facebook, LinkedIn, Twitter, etc. A wide selection of journals (inclusive of 9 subjects, more than 200 journals)

Providing 24-hour high-quality service

User-friendly online submission system

Fair and swift peer-review system

Efficient typesetting and proofreading procedure

Display of the result of downloads and visits, as well as the number of cited articles Maximum dissemination of your research work

Submit your manuscript at: http://papersubmission.scirp.org/

Or contact oje@scirp.org 